\section{СПИСОК ЛИТЕРАТУРЫ}

1. Сухорукова Т.Г. Проблемы информационной защищенности предприятия / Т.Г. Сухорукова // Вісник ХДЕУ. - 1998. - №3 (7). - С. 75-77.

2. Гайденко П.П. Античная философия / П.П. Гайденко // Энциклопедический словарь. - М.: Прогресс - Традиция. - 2008. - 890 с.

3. Богомолов А. С. Античная философия / А.С. Богомолов. - М.: Высшая школа. - 2006. - 390 с.

4. Асмус В. Ф. Кант / В.Ф. Асмус М.: Наука. - 1973. - 532 с.

5. Куликов П.К. Педагогическая антропология / П.К. Куликов. - М.: Знание. - 1986. - 375 с.

6. Терещенко Ю.І. Філософія освіти та пошуки морально-етичного виховання /
Ю.І. Терещенко // Шлях освіти. - 2002. №3. - C. $11-15$.

7. Кибанов А. Я. Управление персоналом: Энциклопедический словарь/ под ред. А. Я. Кибанова - М.: ИНФРА-М, 2008. -560 c.

8. Дикань В. Л. Економіка праці на підприємствах залізничного транспорту: навч. посібник / В.Л. Дикань, Ю.В. Елагін, Т.Г. Сухорукова, 2012. - 345 с.

9. Dessler Gary. Management: Principles \& Practices for Tomorrow's Leaders and Student CD, Third Edition [Електронный pecypc] / Dessler Gary . Режим доступа: http://www.booksprice.ru/ books/89283.html

10. Романенко М. Становление философии образования: на пересечении философии и педагогики / М. Романенко // Персонал. - 2004. - №6. - С. 50-53.

Статья поступила: 5.09.162.

УДК 331.103.22

\title{
ФРІЛАНС ЯК СУЧАСНИЙ ВИД ТРУДОВИХ ВІДНОСИН
}

\author{
Тертичний О. О., к.т.н., доцент (ХІФ КНТЕУ)
}

У статті розглянуто особливості віддаленої форми організаџії праџі у вигляді фрілансу. Проаналізовано основні джерела доходів фрілансерів, визначено джерела інформації щодо розвитку фрілансу, проаналізовано достовірність та репрезентативність изих джерел. Визначено розміри доходів фрілансерів, їх середній заробіток. Усі розрахунки проводилися для фрілансерів, щзо мешкають на території Украӥни і виконують замовлення для організацій в усьому світі. Визначено основні крайни, які використовують фріланс найбільш активно. Проаналізовано недоліки та переваги фрілансу на індивідуальному та макроекономічному рівні. Надано рекомендації щзодо розвитку фрілансу та послабленню його негативних наслідків.

Ключові слова: фріланс, фрілансер, дохід, організація праці, замовлення, віддалена праця.

\section{ФРИЛАНС КАК СОВРЕМЕННЫЙ ВИД ТРУДОВЫХ ОТНОШЕНИЙ}

\section{Тертичный А. О., к.т.н., доцент (ХИФ КНТЭУ)}

В статье рассмотрены особенности удаленной формы организации труда в виде фриланса. Проанализированы основные источники доходов фрилансеров, 
определень источники информации по развитию фриланса, проанализировань достоверность и репрезентативность этих источников. Определены размеры доходов фрилансеров, их средний заработок. Все расчеть проводились для фрилансеров, проживающих на территории Украиныл. Они выполняют заказы для организаций во всем мире. Определень основные страны, которые используют фриланс наиболее активно. Проанализировань недостатки и преимущества фриланса на индивидуальном и макроэкономическом уровне. Даны рекомендации по развитию фриланса и ослаблению его негативных последствий.

Ключевые слова: фриланс, фрилансер, доход, организация труда, заказ, удаленная работа.

\section{FREELANCE AS MODERN VIEW OF LABOR RELATIONS}

\section{Tertichny A.O., PhD, Associate Professor ( Kharkov Institute of FinanceKyiv National University of Trade and Economics)}

The article describes the features of the remote form of work organization in the form of freelancing. Analyzed the main sources of income of freelancers, identified sources of information on the development of freelancing, analyzed the reliability and representativeness of these sources. The sizes of freelance income, their average earnings. All calculations were performed for freelancers, residing in the territory of Ukraine. They carry out an order for organizations worldwide. The main countries that use freelance most active. Analyzed the advantages and disadvantages of freelancing on the individual and the macroeconomic level. The recommendations on the development of freelancing and the weakening of its negative consequences.

Keywords: freelance, freelancer, income, labor organization, order, distant work.

Постановка проблеми. Сьогодні у сфері праці відбуваються активні перетворення. Причинами цих перетворень $є$ кризові процеси у економіці країн, глобалізація, розвиток науковотехнічного прогресу. Виникає велика кількість нових професій та новітніх форм організації праці. Активно розвивається віддалена праця, i, у тому числі, іiї вид фріланс.

Аналіз останніх досліджсень $\boldsymbol{i}$ публікацій. Питання віддаленої праці та фрілансу досліджувалися у роботах зарубіжних дослідників, таких як Кітчинг Дж.[1], Рой М.[2], Малоун Т.В.[3] та ін. Російські вчені також досліджували питання фрілансу. Результати їх досліджень представлені у роботах Гурової М.І.[4], Стребкова Д.О.[5, 6] та ін. Також велику кількість інформації щодо фрілансу можна знайти на спеціалізованих біржах фрілансу, блогах фрілансерів.
Виділення невирішених частин загальної проблеми. Існує низка публікацій щодо розвитку фрілансу, але практично не досліджено вплив розвитку фрілансу на економіку країни. Також невідомий у повному обсязі масштаб економічного впливу фрілансерів на розвиток економіки, усі його позитивні та негативні сторони.

Mema cmammi - проаналізувати розвиток віддаленої праці та фрілансу у сучасній Україні, визначити його національні особливості та розробити методи визначення його впливу на економіку країни. Оцінити рівень доходів фрілансерів. Надати рекомендації щодо посилення його позитивних наслідків та протидії негативним наслідкам.

Викладення основного матеріалу. Сьогодні не існує точного визначення понять фріланс та фрілансер. Перш за все, дамо визначення цих 
термінів. Найбільш повним визначенням на сьогодні $\epsilon$ наступне:

Фріланс - це такий вид організації праці, при якому використовується віддалена робота 3 фіксованим обсягом робіт.

Фрілансер - це робітник, що працює за фрілансом, тобто це позаштатний працівник, який працює віддалено.

Необхідно відмітити, що поява фрілансерів обумовлена тим, що в епоху постіндустріалізму стають більш затребуваними професії, пов'язані 3 виробництвом і переробкою інформації, наданням послуг у вигляді проектів. При цьому представникам цих інтелектуальних професій не потрібно перебувати в офісі повний робочий день. Стають потрібними люди, готові працювати творчо, проектно, тимчасово і віддалено. 3 іншого боку, $\epsilon$ бажаючі знайти власний баланс в житті між роботою, сім'єю, дозвіллям i отриманням освіти. Саме такі люди обирають фріланс.

Найбільшу кількість інформації щодо фрілансерів можна зібрати, розглядаючи існуючі біржі фрілансу, або сайти рекрутингових компаній. Однією 3 таких компаній $є$ рекрутингова компанія top\$dev [7], на сайті якої можна знайти велику кількість аналітичної інформації. На сайті top\$dev знаходяться профілі розробників програмного забезпечення та інших IT-спеціалістів, що формується і регулярно оновлюється 3 багатьох відкритих джерел типу odesk, elance, freelance та ін.; всі дані з різних джерел узгоджуються між собою (за єдиним довідником навичок, міст), доповнюються можливістю додаткового пошуку на pecypcax типу linkedin, github і по фото. Тому дані, представлені на цьому сайті, можна вважати репрезентативними для даного дослідження. Проаналізуємо ці дані.

Найбільш активно серед європейських країн фрілансом займаються представники України (28362 розробника), Росії (24168 розробників) та
Румунії (13012 розробників). На фрілансмайданчику Freelancehunt [8] за підсумками першого півріччя 2015 року зростання кількості користувачів склало близько $30 \%$ (зараз на сервісі працює майже 134 тис. фрілансерів), а кількість опублікованих щодня проектів у порівнянні 3 аналогічним періодом минулого року збільшилася в два рази. На сайті freelance.ua кількість фрілансерів складає 28 тис чол., на біржі http:/qvp.ua/ кількість виконавців складає 5 тис, на http://free-lance.ua зареєстровано 11 тис виконавців. Фрілансер може бути одночасно зареєстрованим на декількох порталах. Таким чином, можна вважати, що фрілансом на території України займаються 134 тис. осіб.

Цікавим питанням $\epsilon$ визначення розміру заробітку в результаті фрілансу.

Найбільше замовлень українські фрілансери виконали в IT-сфері та дизайні: на 32 млн. доларів і 2 млн. доларів відповідно. Крім того, роботу знайшли копірайтери та перекладачі (заробили 133,4 тис. доларів), фінансисти та управлінці (62,1 тис. доларів), системні адміністратори (51,9 тис. доларів), фахівці у сфері розробки та промислового виробництва (45,5 тис. доларів), а також в галузі продажів і маркетингу $(34,6$ тис. доларів) [9].

Слід зазначити, що $є$ два типи фрілансерів - новачки i професіонали. Їхній заробіток практично неможливо порівняти. Якщо новий робітник часто працює безкоштовно за відгук або наповнення портфоліо, то професіонал може навіть відмовитися від дорогих замовлень, тому що, наприклад, вони йому не подобаються, або у нього немає настрою. Висококласні фрілансери мають погодинну ставку до 80 доларів США. Тому найбільш вигідно працювати фрілансерами - - досвідченим професіоналам. Адже саме на них в першу чергу звертають свою увагу роботодавці. Але новачкам, в свою чергу, доводиться виконувати багато завдань за невеликі гроші, щоб спочатку наповнити своє 
портфоліо. Також існують працівники, фрілансерів для країн світу наведені у для яких фріланс являється вторинною таблиці 1. Доля фрілансерів 3 України зайнятістю.

За даними рекрутингової компанії top\$dev[7], розміри замовлень для серед усіх фрілансерів світу складає на 22,9\%[7]. До таблиці включено 10 країн, розмір замовлень яких найбільші.

Таблийа 1

Обсяги замовлень фрілансерів

\begin{tabular}{|l|c|c|c|}
\hline \multicolumn{1}{|c|}{ Країна } & $\begin{array}{l}\text { Розмір замовлень, } \\
\text { усього, тис. } \\
\text { доларів США }\end{array}$ & $\begin{array}{l}\text { Обсяг } \\
\text { замовлень, що } \\
\text { виконують } \\
\text { фрілансери } 3 \\
\text { Україн, тис. } \\
\text { доларів США }\end{array}$ & $\begin{array}{l}\text { Доля замовлень, } \\
\%\end{array}$ \\
\hline США & 40266 & 59,0 \\
\hline Великобританія & 23593 & 5403 & 7,9 \\
\hline Австралія & 21964 & 5030 & 7,4 \\
\hline Канада & 19242 & 4406 & 6,5 \\
\hline Германія & 7950 & 1821 & 2,7 \\
\hline Франція & 4800 & 1099 & 1,6 \\
\hline Нідерланди & 4675 & 1071 & 1,6 \\
\hline Швеція & 4369 & 1001 & 1,5 \\
\hline Данія & 4291 & 983 & 1,2 \\
\hline Швейцарія & 3541 & 811 & \\
\hline Усього по світу & 297981 & 68238 & \\
\hline
\end{tabular}

Як можна побачити 3 таблиці, найбільшу кількість замовлень для фрілансерів з України надають компанії з США, до першої п'ятірки також входять Великобританія, Австралія, Канада, Германія. Доля замовлень для інших країн не перевищує $2 \%$.

Обсяг замовлень фрілансерів України складає 68238 тис. доларів США, кількість фрілансерів складає 134 тис. особи, за рік на одного фрілансера приходиться 509 дол. США, або 42 дол. США на місяць. Як можна побачити 3 цих даних, персонал, працюючий за фрілансом, $є$ одним 3 інструментів розвитку економіки України. Його необхідно розвивати. Але у такої організації праці є і недоліки.

Розглянемо особливості фрілансу на різних рівнях. На індивідуальному рівні він має наступні позитивні риси:

1. Відносини між робітником та роботодавцем будуються на партнерських відносинах. Вони $є$ рівноправними партнерами. Необхідно враховувати інтереси обох сторін, конфліктні рішення вирішуються шляхом консенсусу.

2. Вільний вибір робочого часу. Фрілансер сам вибирає час роботи, працюе тоді, коли йому це йому сподобається і зручно. Він сам визначає баланс свого робочого та вільного часу, термін початку та закінчення робочого дня.

3. Вільний вибір напряму робіт. Фрілансер самостійно визначає напрям, за яким він працює. Аналізуючи ситуацію на ринку праці, можна вибрати напрям, за яким необхідно професійно розвиватися. Питаннями підвищення кваліфікації він повинен займатися самостійно.

4. Можливість одночасно виконувати декілька замовлень, навіть для конкуруючих організацій. Досить часто замовник не знає, з ким ще співпрацює фрілансер.

5. Можливість знаходити роботу за межами місця проживання, навіть у іншій країні. 
6. Можливість багаторазово передавати замовнику типові шаблонні замовлення, наприклад Інтернет-магазини та ін. Це дає можливість продати виконану роботу неодноразово.

7. Для роботодавця використання послуг фрілансера може знизити податковий тиск, а також спростити документообіг.

8. Фрілансерам зазвичай передаються разові, не типові для організації роботи: одноразове створення сайту, прибирання приміщень та ін.

Серед недоліків такої організації роботи можна визначити наступне:

1. Відсутність соціального захисту. Також можуть виникнути труднощі у отриманні віз, кредитів, соціальних послуг через неможливість надати інформацію про рівень доходів.

2. Необхідність самостійно організовувати своє робоче місце. Обладнання для роботи фрілансер придбає самостійно, за власний кошт.

3. Відсутність стабільного заробітку. Якщо не буде замовлень, не буде і заробітку.

4. Самостійне ведення податкового обліку. Але його ведення, особливо на єдиному податку, на сьогодні не є дуже складним.

Цікавим $є$ питання значення фрілансу для суспільства. 3 позитивних сторін такої організації праці на макроекономічному рівні є наступні риси:

1. Фрілансери мають велику свободу на ринку праці у визначенні замовлення і ціни, що сприяє розвитку та активізації цього ринку.

2. Вони мають можливість виконувати роботи для замовників з інших країн, що дозволяє отримувати валюту для країни, при цьому їх заробітки є більшими за середні по країні.

3. Під час роботи на закордонну компанію фрілансери отримують досвід роботи, який починають використовувати в своїй країні. Відбувається активний обмін досвідом на міжнародному рівні.
4. Фрілансери та IT- сектор сьогодні є потужнім джерелом валюти для країни.

5. Активна робота фрілансерів сприяє глобалізаційним процесам.

Але така організація праці має i низку недоліків:

1. Досить часто фрілансери не платять податки, або платять їх не у повному обсязі.

2. Доходи, що отримують фрілансери, як і будь-які тіньові доходи, приводять до розвитку корупції та тіньової економіки.

3. Фрілансери не можуть створювати політичні лобістські організації, вони виявляються політично пасивними. Це приводить до послаблення розвитку соціального партнерства в Україні.

4. Діяльність фрілансера не пов'язана з територією країни, у випадку погіршення економічної або політичної ситуації він може вільно змінити місце проживання. Також висококваліфікованим робітникам закордонні організації оказують допомогу у переїзді.

Висновки. Фріланс є сучасною та прогресивною формою зайнятості. Він має велику кількість переваг. Тому сьогодні відбувається активний розвиток такої форми організації праці. Це пов'язано 3 складною економічною ситуацією, високим курсом іноземної валюти, складною ситуацією на ринку праці. Ринок фрілансу в Україні розвивається швидкими темпами, залучаючи все нових учасників як 3 боку виконавців, що пропонують свої послуги, так і 3 боку приватних осіб і організацій, готових до співпраці на віддаленій основі. Але діяльність фрілансерів сьогодні на законодавчому рівні повністю не врегульована. Існують проблеми і у сфері соціального захисту такої категорії працівників. Тому необхідно підвищити соціальну активність фрілансерів, надавши їм можливість стати повноцінними учасниками суспільного життя. 


\section{СПИСОК ЛІТЕРАТУРИ}

1. Kitching J. Defining and estimating the size of the UK freelance workforce [Electronic resource] / J.Kitching, D.Smallbone // A Report for the Professional Contractors Group. - October, 2008. - P. v-x; 1-46. - Access mode: http://www.pcg.org.uk/cms/documents/POLI CY_AND_CAMPAIGNS

/research/Defining_and_estimating_thesizeof the_freelance_workforce-

FULL_REPORT.pdf

2. Mill Roy. Hiring and Learning in Online Global Labor Markets [Electronic resource] /Mill Roy // Working Paper.October, 2011. - No. 11-17. - P. 1-25. Access mode: http://www.netinst.org/Mill_11_17.pdf.

3. Thomas W. Malone. The Dawn of the E-Lance Economy [Electronic resource] / Thomas W. Malone, Robert J. Laubacher // Harvard business review. - SeptemberOctober,1998. - P. 145-152. - Access mode: http://www. ecopywriters. com/downloads/dawn-elance-econ.pdf

$$
\text { 4. Гурова М.И. Факторы, }
$$
влияющие на выбор фриланса как формы самозанятости [Электронный ресурс] / M. И. Гурова // Теория и практика общественного развития. - 2012. - № 7. Режим доступа: http://teoria-practica.ru/-72012/sociology/gurova.pdf.

5. Стребков Д. О. Фрилансеры в информационной экономике: мотивация и организация труда [Электронный ресурс] /Д.О. Стребков, А.В. Шевчук. - Режим доступа:

http://soc.hse.ru/data/2009/12/02/123839013

3/Strebkov-hevchuk_SocReal_01-2008.pdf.

6. Стребков Д.О. Фрилансеры на российском рынке труда [Электронный ресурс] / Д.О. Стребков, А.В. Шевчук // Социологические исследования. - 2010. № 2. - С. 45-55. - Режим доступа: http://dlib.eastview.com/browse/doc/2197337 4.

7. top $\$$ dev. Сервис поиска
программистов, системных администраторов, тестировщиков, вебдизайнеров [Электронный ресурс]. Режим доступа: https://topsdev.org/

8. Freelancehunt. Сервис для поиска удаленной работы и фриланс-проектов [Электронный ресурс]. - Режим доступа: https://freelancehunt.com/

9. Elance joins the Upwork
community: Статистика Вакансії
[Электронный pecypc]. - Режим доступа:
https://www.elance.com/i/f/statistics

Стаття надійшла: 12.09.16р. 